\title{
Technology Acceptance Model, Organizational Commitment and Turnover Intention: A Conceptual Framework
}

\author{
Alireza Parvari ${ }^{1}$, Roya Anvari ${ }^{2}$, Nur Naha binti Abu Mansor ${ }^{1}$, Masoomeh Jafarpoor ${ }^{3} \&$ Maliheh Parvari ${ }^{4}$ \\ ${ }^{1}$ Department of HRD, Faculty of management, Universiti Teknologi Malaysia, Skudai, Malaysia \\ ${ }^{2}$ Isfahan University of Medical Sciences, Iran \\ ${ }^{3}$ Department of Business Administration, Faculty of Management, Universiti Teknologi Malaysia, Skudai, \\ Malaysia \\ ${ }^{4}$ Islamic Azad University E_Campus, Iran \\ Correspondence: Roya Anvari, Isfahan University of Medical Sciences, Iran. E-mail: ry_anvari@yahoo.com
}

Received: June 15, 2015 Accepted: August 3, $2015 \quad$ Online Published: November 13, 2015

doi:10.5539/res.v7n12p146

URL: http://dx.doi.org/10.5539/res.v7n12p146

\begin{abstract}
Information system is being implemented to improve job performance and facilitate employees' work. However, implementing Information system has some negative impacts on employees and organization if employees do not accept it. Several previous studies investigated some consequences of information technology such as turnover intention and job satisfaction. This study provides a conceptual framework that shows other independent consequences of information system implementation. The model presented the impact of attitude towards using information technology on three components of organizational commitment (formative, normative and continuance). It also addresses the impact of attitude towards using information technology on turnover intention directly and via organizational commitment. Based on technology acceptance and its consequences, we develop a number of testable propositions that can guide to further research on work related outcome due to technology acceptance. Finally, we provide some recommendations for future research.
\end{abstract}

Keywords: TAM, organizational commitment, IT acceptance, turnover intention

\section{Introduction}

Information technology (IT) is becoming more important than at any time in the past. It allows organizations to raise performance in almost every area of operation, including cycle time, inventories, manufacturing, and customer support in marketing and distribution (Dwivedi, 2011). Information system implementation has many advantages, although it has some disadvantages if it is not accepted by users. Information systems (IS) have an influence on organizational performance. IS generally adds value to an organization, its performance and activities that contributes it to stay competitive in today's globalized world. IS heavily facilitates internal coordination and plays an important role to decrease internal coordination cost. Information systems are heavily reliant on facilitating internal coordination and play a significant role to reduce internal coordination cost (Dwivedi, 2011). Beside these advantages, it has also some negative impacts on an organization if employees do not accept it. Joshi and Lauer (1998) pointed out some negative impacts of information system implementation. They asserted that Information technology or system (IT/IS) in particular a computer aided design (CAD) system implementation may have an effect on user's work environment in different manners. Some of the effects may not be favorable for user that can lead to negative consequences such as increased stress, reduced commitment and job satisfaction.

Among the various models that IT research has used to explain and predict user acceptance behavior, the Technology Acceptance Model (TAM), provided by Davis (1989) and Davis et al. (1989) may be the most widely applied model. The key reasons for its prevalent use are its simplicity, cost-cutting along with robustness (Abbasi et al., 2011; Chang, 2010; Lee \& Lehto, 2013; Lee et al., 2013). TAM illustrates that individuals' perceptions based on perceived ease of use (PEOU) and perceived usefulness (PU) influence user's intention and usage behaviors towards a special IT (Davis, 1989; Davis et al., 1989). However, some scholars claimed that the relationship between attitude toward using Information Technology (ATU) and intention behaviors does not hold true especially when technology usage is not voluntary (Brown et al., 2002; Teo, 2011). Moreover, Brown et al. (2002) suggested that "attitudes can have a significant influence on an individual's perception toward the work 
environment and organization" (p. 291).

However, Maier et al. (2013), followed the Brown et al. (2002) suggestion and examined the effect of human resource information system implementation on turnover intention and job satisfaction as two work related outcomes. These authors report that attitudes have a notable impact on an individuals' perception toward the organization and work environment. In particular, the authors found a significant and indirect positive impact of attitude towards using information system on TI through job satisfaction. They also suggested to add organizational commitment to their model to decrease turnover intention. Subsequently, Parvari et al. (2014) provided a conceptual framework that shows the relationship between attitude towards using IT and Psychological contract led to organizational commitment and turnover intention. It appears that Parvari et al. (2014) ignored to show the effect of attitude towards using IT on turnover intention (TI) directly and via organizational commitment (OC) as well as on organizational commitment directly. Filling this gap, present study investigated the effect of attitude towards using IT on TI through OC. Before presenting the model, TAM, OC and TI construct is briefly discussed.

\section{Technology Acceptance Model (TAM)}

The TAM is a revision of the theory of reasoned action. Davis (1989) asserted that intentions to use IT determines IT adoption behaviors by two factors: usefulness and ease of use. Ease of use is described as the degree to which a user hopes the target system is user friendly and usefulness reflects to a degree that usage of a specific IT application can increase user's job performance. The initial Technology Acceptance Model theorizes the relations between beliefs, attitude and behavioral intentions to forecast users' adoption of IT. Previous studies proved the validity in forecasting users acceptance behaviors across contextual settings and technologies (Carayannis, 2013; Piaggesi et al., 2011).

\section{Organizational Commitment (OC)}

The meaning of OC is deeply rooted in previous studies. Meyer and Allen (1988) and Porter et al. (1974) emphasize on the dimensions of the employees' emotional attachment. Individuals' attitude towards their job has attracted the attention of researchers because it has been frequently indicated that there was an relation between emotional attachment and commitment to the organization and the employees' intentions to leave that organization (Gaines and Jermier, 1983). Moreover, Stiffler (2007) pointed out that OC can predict the intent to leave better than job satisfaction does. Allen and Meyer (1990b) and Allen and Meyer (1990a) propose and conduct three dimensions of OC: affective commitment, continuance commitment and normative commitment. These three dimensions of $\mathrm{OC}$ will be described as follow:

Affective Commitment (AC): one of the most applied factor of OC is affective dimension (Cole and Johnson, 2007; Kwantes, 2009). Cole and Johnson (2007) and Meyer et al. (1991) described AC as an emotional attachment to the organization. AC refers to employees' involvement in, emotional attachment to, and identification with the organization (Meyer and Allen, 1988).

Normative Commitment (NC): Kobylarek et al. (2013) defined NC as the degree of commitment that the employees' want to stay in their organization. Bolon (1996) defined NC as individuals' beliefs towards the organization or their sense of commitment to their job.

Continuance Commitment (CC): Allen and Meyer (1996) defined CC as the degree which an employee needs to continue working with an organization since the expense of leaving is too high. Meyer et al. (1991) they found it difficult to find alternative job, so they prefer to continue their work to increase their commitment.

\section{Turnover Intention (TI)}

The concept of leaving the current position or organization (Mowday et al., 1982a); the series of perceptions in retreating cognition (Tett and Meyer, 1993). Rumery (1998) defines TI as the expectation of actual turnover. TI reflects to the deliberate and conscious intention of employees to quit the organization (San Park \& Kim, 2009).

\section{Turnover Intention Theories}

Social exchange theory provided by Homans (1958) is known as an important theory that explains OC as a predictor of TI. According to this theory, workers seek for mutual beneficial relationship with their organization. If they feel their organization does not fulfill the obligation they reduce OC and increase TI.

\section{Effects of Turnover Intention}

Phillips (1990) pointed out that turnover imposes many hidden or invisible costs, and consequently these invisible costs are passed on to the remaining co-workers, such as the cost of training replacements for employees who have quit. The cost of training workers will have finally effect on the profit of the organization. Meanwhile, turnover 
costs the organization in terms of human resources, productivity and employee morale. Consequently, this will have an impact on the organization's earnings. Many investigators argued that the high rate of turnover if it is not managed as well, it will have a negative impact on the profitability of organizations (Duraisingam et al., 2009; Tiamiyu et al., 2009).

\section{An Integrated Model of TAM, Organizational Commitment and Turnover Intention}

The theoretical propositions discussed in this paper are illustrated in an overall model displayed in Figure 1. The model has some important characteristics.

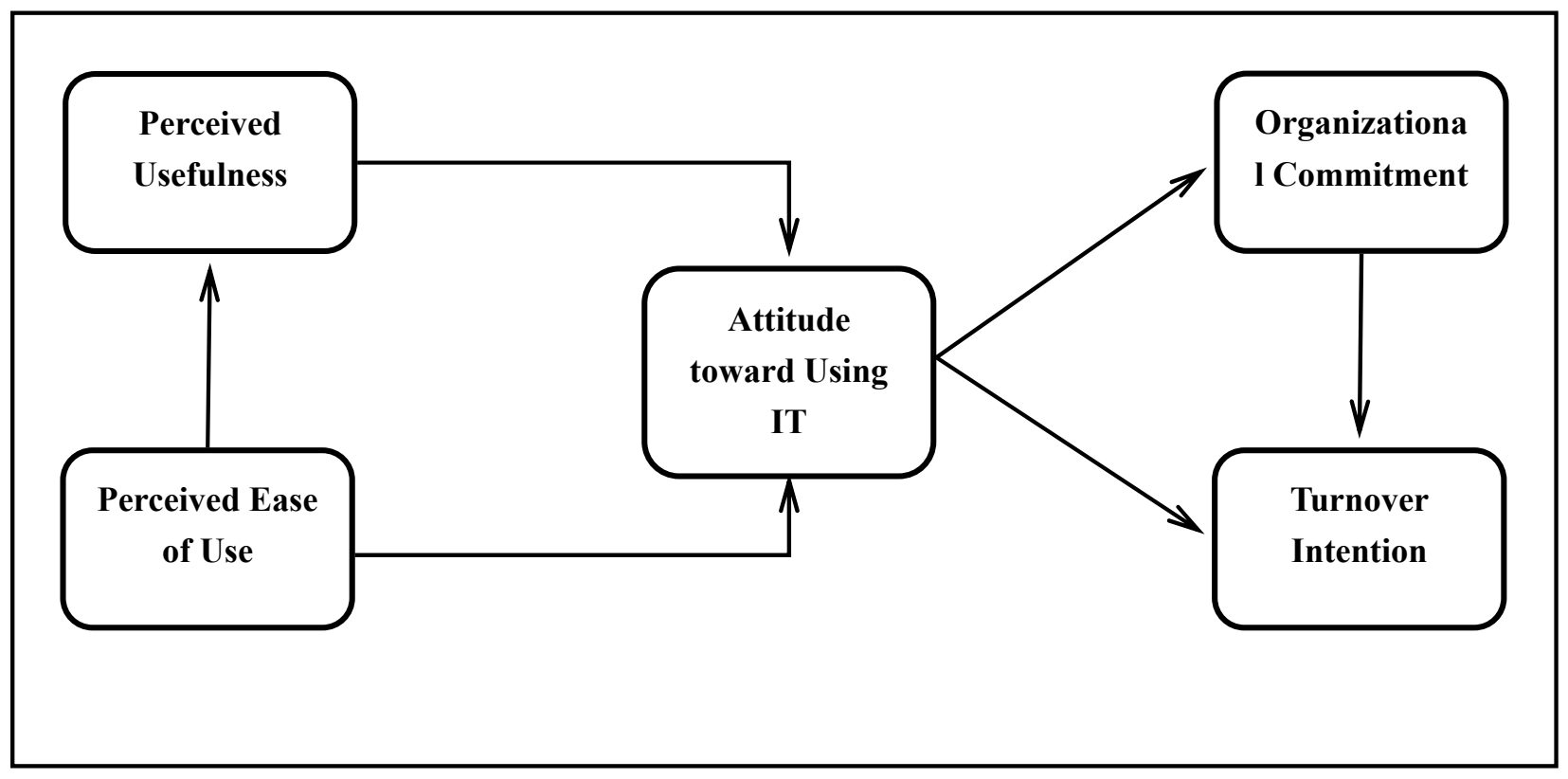

Figure 1. Conceptual framework

First, the model considers the relationship between three dimensions of OC (formative, normative and continuance) and TI. The effect of attitude towards information technology may be different on various dimensions of OC that in turn may have different effects on TI. Therefore, analyzing the model can reveal significant insights on the effect of different dimensions of OC on TI.

Second, the model integrates TAM into IT field with work related outcomes from organizational behavior field. The model focuses on employees' attitudes and behavioral intentions due to IT implementation when IT usage is mandatory. As a result, the model shows the linkage between attitudes towards IT with OC as an attitude towards organization and turnover as a behavioral intention.

\section{The Relationship between Attitude towards using IT (ATU) and Organizational Commitment (OC):}

Individuals are employed in the organizations with certain skills, expectations, requirements, and they expect to meet a work environment to utilize their abilities and fulfill their requirements. When organizations are able to provide these chances, likely commitment will be increased. Porter et al (1976) define OC as the relative intensity of an individual's identity and involvement in a specific organization. Mowday et al. (1982b) consider commitment as an attitude that indicates the quality and nature of relationship between an organization and an employee. It is a condition in which individuals identify with a specific organization and their goals and wish to stay as membership in that organization to facilitate their goals. Buchanan (1974) argue that commitment often creates an exchange of relation in which an individual attach to the organization to receive certain award from the organization. Therefore, if an IT present good quality in performance and easy to use by affecting employees' perception of organization can support the linkage between an employee and an organization and consequently increase employees' OC. Thus, the following proposition is formulated:

Proposition 1. Attitude towards using IT is positively associated with Organizational commitment. 


\section{The Relationship between Attitude towards using IT (ATU) and Turnover Intention (TI):}

The impact of rising TI is corroborated as employees feel the rising pressure related with gaining new skills (Lukaszewski et al., 2008) to fulfill the requests for cost reduction (Bondarouk and Ruël, 2009), to exploit process improvements (Tansley et al., 2001), as well as to realize time savings (Strohmeier, 2007), in way which they can employ well qualified personnel in minimum time. Ferratt (2005) suggested that a task focused orientation of a human resource, focuses particularly on increasing a worker's short-term performance, and generates a higher level of turnover than configuration that focuses on the worker. When a worker's role changes after implementing information technology (Wiblen et al., 2010), she/he could be dissatisfied or even leave the job. As a result, the implementation of information technology changes worker's role and also their work routines. When employees do not like these changes, they evaluate the new implemented information technology a cause for such changes in a negative way or vice versa. Therefore, the following proposition is formulated:

Proposition 2. Attitude towards using IT is positively associated with turnover intention

\section{The Relationship between Organizational Commitment (OC) and Turnover Intention (TI):}

Results from previous study revealed that employees with a high level of OC are less likely to have intent to leave than employees who are not relatively committed (Al Arkoubi et al., 2011). A meta-analysis of forty-two studies indicated that OC can predict the actual turnover better than job satisfaction does (Gaertner, 2000). Therefore, the following proposition is formulated:

Proposition 3. Organizational commitment is positively related with turnover intention

\section{Additional Directions for Research}

There are some considerations that researchers are required to take when testing some of the propositions incorporated in the model. First, the model involves individual levels of analysis. Indeed, respondents are employees who work routinely with IT based on computer as a tool work. Second, respondents need to work with IT routinely so that their main concern with job is quality of the system that they are working with. Because using the IT for short time may not lead to intention to leave the job. Third, ease of use and perceived usefulness are quality characteristics of general IT. As this paper aimed at work related outcomes, and rate of TI for each employee can be measured by IT that employee is using.

\section{Conclusion}

Utilizing TAM, this study provides a theoretical proposition that shows the impact of attitude towards using IT on TI through OC. In other word, this study integrates TAM with work related outcome constructs. Moreover, the study of "outcomes in technology adoption research is very limited" (Venkatesh et al., 2007, p. 277), especially the consequences of workers' negative attitude towards an IT. However, we propose a number of propositions that can help researchers in this field. Future research may benefit from analyzing these propositions to determine the rate of TI due to IT implementation in organizations. In addition, the results of analyzing these propositions may be useful for organizational managers to understand the need for successful IT implementation and organizational programs that enable the organization to establish employees' positive attitude towards IT and positive employer-employee relationships in order to reduce TI.

\section{Recommendation}

Employees with different cultural backgrounds in different countries show different levels of system usage (Lee, Trimi et al., 2013). It would be interesting to analyze the model for different individuals with different cultural backgrounds. In addition, the future research could analyze whether system implementation affects OC more at early steps or when workers use it in their routine work.

\section{References}

Abbasi, M. S., Chandio, F. H., Soomro, A. F., \& Shah, F. (2011). Social influence, voluntariness, experience and the internet acceptance: An extension of technology acceptance model within a south-Asian country context. Journal of Enterprise Information Management, 24(1), 30-52. http://dx.doi.org/10.1108/17410391111097410

Al Arkoubi, K., Bishop, J. W., \& Scott, D. (2011). An Investigation of the Determinants of Turnover Intention Among Drivers.

Allen, N. J., \& Meyer, J. P. (1990a). The measurement and antecedents of affective, continuance and normative commitment to the organization. Journal of occupational psychology, 63(1), 1-18. http://dx.doi.org/10.1111/j.2044-8325.1990.tb00506.x 
Allen, N. J., \& Meyer, J. P. (1990b). Organizational socialization tactics: A longitudinal analysis of links to newcomers' commitment and role orientation. Academy of Management Journal, 33(4), 847-858. http://dx.doi.org/10.2307/256294

Allen, N. J., \& Meyer, J. P. (1996). Affective, continuance, and normative commitment to the organization: An examination of construct validity. Journal of vocational behavior, 49(3), 252-276. http://dx.doi.org/10.1006/jvbe.1996.0043

Bolon, D. S. (1996). Organizational citizenship behavior among hospital employees: A multidimensional analysis involving job satisfaction and organizational commitment. Hospital \& Health Services Administration, 42(2), 221-241.

Bondarouk, T., \& Ruël, H. (2009). Electronic Human Resource Management: Challenges in the digital era. The International Journal of Human Resource Management, 20(3), 505-514. http://dx.doi.org/10.1080/09585190802707235

Brown, S. A., Massey, A. P., Montoya-Weiss, M. M., \& Burkman, J. R. (2002). Do I really have to? User acceptance of mandated technology. European journal of information systems, 11(4), 283-295. http://dx.doi.org/10.1057/palgrave.ejis.3000438

Buchanan, I. (1974). Building organizational commitment: The socialization of managers in work organizations. Administrative science quarterly, 19(4).

Carayannis, E. G. (2013). Creating a Sustainable Social Ecology Using Technology-driven Solutions. Information Science Reference. http://dx.doi.org/10.4018/978-1-4666-3613-2

Chang, C.-K. (2010). Acceptability of an asynchronous learning forum on mobile devices. Behaviour \& Information Technology, 29(1), 23-33. http://dx.doi.org/10.1080/01449290701806337

Cole, P. M., \& Johnson, K. (2007). An exploration of successful copreneurial relationships postdivorce. Family Business Review, 20(3), 185-198. http://dx.doi.org/10.1111/j.1741-6248.2007.00093.x

Davis, F. D. (1989). Perceived usefulness, perceived ease of use, and user acceptance of information technology. MIS quarterly, 13(3), 319-340. http://dx.doi.org/10.2307/249008

Davis, F. D., Bagozzi, R. P., \& Warshaw, P. R. (1989). User acceptance of computer technology: A comparison of two theoretical models. Management science, 35(8), 982-1003. http://dx.doi.org/10.1287/mnsc.35.8.982

Duraisingam, V., Pidd, K., \& Roche, A. M. (2009). The impact of work stress and job satisfaction on turnover intentions: A study of Australian specialist alcohol and other drug workers. Drugs: Education, Prevention, and Policy, 16(3), 217-231. http://dx.doi.org/10.1080/09687630902876171

Dwivedi, Y. K. (2011). Information Systems Theory: Explaining and Predicting Our Digital Society (Vol 1). Springer.

Ferratt, T. W., Agarwal, R., Brown, C. V., \& Moore, J. E. (2005). IT human resource management configurations and IT turnover: Theoretical synthesis and empirical analysis. Information systems research, 16(3), 237-255. http://dx.doi.org/10.1287/isre.1050.0057

Gaertner, S. (2000). Structural determinants of job satisfaction and organizational commitment in turnover models. Human resource management review, 9(4), 479-493. http://dx.doi.org/10.1016/S1053-4822(99)00030-3

Gaines, J., \& Jermier, J. M. (1983). Emotional exhaustion in a high stress organization. Academy of Management Journal, 26(4), 567-586. http://dx.doi.org/10.2307/255907

Homans, G. C. (1958). Social behavior as exchange. American journal of sociology, 597-606. http://dx.doi.org/10.1086/222355

Joshi, D. K., \& Lauer, D. T. W. (1998). Impact of information technology on users' work environment: A case of computer aided design (CAD) system implementation. Information \& Management, 34(6), 349-360. http://dx.doi.org/10.1016/S0378-7206(98)00069-X

Kwantes, C. T. (2009). Culture, job satisfaction and organizational commitment in India and the United States. Journal of Indian Business Research, 1(4), 196-212. http://dx.doi.org/10.1108/17554190911013265

Lee, D. Y., \& Lehto, M. R. (2013). User acceptance of YouTube for procedural learning: An extension of the technology acceptance model. Computers \& Education, 61, 193-208. http://dx.doi.org/10.1016/j.compedu.2012.10.001 
Lee, S. G., Trimi, S., \& Kim, C. (2013). The impact of cultural differences on technology adoption. Journal of World Business, 48, 20-29. http://dx.doi.org/10.1016/j.jwb.2012.06.003

Lee, Y.-H., Hsieh, Y.-C., \& Chen, Y.-H. (2013). An investigation of employees' use of e-learning systems: Applying the technology acceptance model. Behaviour \& Information Technology, 32(2), 173-189. http://dx.doi.org/10.1080/0144929X.2011.577190

Lukaszewski, K. M., Stone, D. L., \& Stone-Romero, E. F. (2008). The effects of the ability to choose the type of human resources system on perceptions of invasion of privacy and system satisfaction. Journal of Business and Psychology, 23(3-4), 73-86. http://dx.doi.org/10.1007/s10869-008-9074-0

Maier, C., Laumer, S., Eckhardt, A., \& Weitzel, T. (2013). Analyzing the impact of HRIS implementations on HR personnel's job satisfaction and turnover intention. The Journal of Strategic Information Systems, 22(3), 193-207. http://dx.doi.org/10.1016/j.jsis.2012.09.001

Meyer, J. P., \& Allen, N. J. (1988). Links between work experiences and organizational commitment during the first year of employment: A longitudinal analysis*. Journal of occupational psychology, 61(3), 195-209. http://dx.doi.org/10.1111/j.2044-8325.1988.tb00284.x

Meyer, J. P., Bobocel, D. R., \& Allen, N. J. (1991). Development of organizational commitment during the first year of employment: A longitudinal study of pre-and post-entry influences. Journal of Management, 17(4), 717-733. http://dx.doi.org/10.1177/014920639101700406

Mowday, R. T., Porter, L. W., \& Steers, R. (1982a). Organizational linkages: The psychology of commitment, absenteeism, and turnover.

Mowday, R. T., Porter, L. W., \& Steers, R. M. (1982b). Employee-organization linkages: The psychology of commitment, absenteeism, and turnover (Vol. 153). Academic Press New York.

Parvari, A., Mansor, N. N. B. A., Jafarpoor, M., \& Salehi, H. (2014). The Study of Consequences of Acceptance Technology When It Is Mandatory: A Conceptual Framework. Review of European Studies, 6(4), 209. http://dx.doi.org/10.5539/res.v6n4p209

Phillips, J. D. (1990). The price tag on turnover. Personnel Journal, 69(12), 58-61.

Piaggesi, D., Castelnovo, W., \& Sund, K. J. (2011). Global Strategy and Practice of E-governance: Examples from Around the World. Information Science Reference. http://dx.doi.org/10.4018/978-1-60960-489-9

Porter, L. W., Crampon, W. J., \& Smith, F. J. (1976). Organizational commitment and managerial turnover: A longitudinal study. Organizational Behavior and Human Performance, 15(1), 87-98. http://dx.doi.org/10.1016/0030-5073(76)90030-1

Porter, L. W., Steers, R. M., Mowday, R. T., \& Boulian, P. V. (1974). Organizational commitment, job satisfaction, and turnover among psychiatric technicians. Journal of Applied Psychology, 59(5), 603. http://dx.doi.org/10.1037/h0037335

Rumery, S. M. (1998). A cross-level analysis of the influence of group-level turnover on individual-level intent to turnover. University of Connecticut.

San Park, J., \& Kim, T. H. (2009). Do types of organizational culture matter in nurse job satisfaction and turnover intention? Leadership in Health Services, 22(1), 20-38. http://dx.doi.org/10.1108/17511870910928001

Stiffler, K. L. (2007). Direct support staff perceptions of frontline supervisor's skills: Correlation with organizational commitment and intent to leave. ProQuest.

Strohmeier, S. (2007). Research in e-HRM: Review and implications. Human resource management review, 17(1), 19-37. http://dx.doi.org/10.1016/j.hrmr.2006.11.002

Tansley, C., Newell, S., \& Williams, H. (2001). Effecting HRM-style practices through an integrated human resource information system: An e-greenfield site? Personnel Review, 30(3), 351-371. http://dx.doi.org/10.1108/00483480110385870

Teo, T. (2011). Technology Acceptance in Education. Sense Publishers. http://dx.doi.org/10.1007/978-94-6091-487-4

Tett, R. P., \& Meyer, J. P. (1993). Job satisfaction, organizational commitment, turnover intention, and turnover: Path analyses based on meta-analytic findings. Personnel psychology, 46(2), 259-293. http://dx.doi.org/10.1111/j.1744-6570.1993.tb00874.x 
Tiamiyu, S., Akintola, J., \& Rahji, M. (2009). Technology adoption and productivity difference among growers of new rice for Africa in savanna zone of Nigeria. Tropicultura, 27(4), 193-197.

Venkatesh, V., Davis, F. D., \& Morris, M. G. (2007). Dead or alive? The development, trajectory and future of technology adoption research. Association for Information Systems, 8(4), 268-284.

Wiblen, S., Grant, D., \& Dery, K. (2010). Transitioning to a new HRIS: The reshaping of human resources and information technology talent. Journal of Electronic Commerce Research, 11(4), 251-267.

\section{Copyrights}

Copyright for this article is retained by the author(s), with first publication rights granted to the journal.

This is an open-access article distributed under the terms and conditions of the Creative Commons Attribution license (http://creativecommons.org/licenses/by/3.0/). 